2. Sprava Khan proty Obiednanoho Korolivstva [The case of Khan v. The United Kingdom]. https://zakon.rada.gov.ua/laws/show/980 020 in Ukrainian).

3. Sprava Svietina proty Slovenii [The case of Svetina v. Slovenia]. http://napu.com.ua/wp-content/uploads/2018/08/SVETINA-protiSloveniyi.pdf (in Ukrainian)

4. Kret, H.R. (2020) Mizhnarodni standarty dokazuvannia u kryminalnomu protsesi Ukrainy [International standards of proof in the criminal process of Ukraine: theoretical, legal and practical foundations]. Kalush: Petrash K.T. (in Ukrainian).

5. Zeikan, Ya.P. (2019) Pro nedopustymi dokazy [On inadmissible evidence]. Kh.: Faktor, (in Ukrainian).

6. Panova, A.V. (2017) Vyznannia dokaziv nedopustymymy u kryminalnomu provadzhenni [Recognition of evidence inadmissible in criminal proceedings]. Kh.: Pravo (in Ukrainian).
7. Zubarev, A.A. (2010) Pravovыe posledstvyia pryznanyia dokazatelstv nedopustymbmy $v$ uholovnom protsesse [Legal consequences of recognition of evidence inadmissible in criminal proceedings] [avtoref. dys. kand. yuryd. nauk]. M. (in Russian)

8. Kostenko, R. V. (2016) Yskliuchenye dokazatelstv, poluchennыkh s narushenyem trebovanyi UPK RF, v khode dosudebnoho proyzvodstva po uholovnum delam []. Obshchestvo y pravo [], (3 (57), 113-117 (in Russian).

9. Kozhevnykova, Yu.A. (2005) Yskliuchenye nedopustymukh dokazatelstv yz razbyratelstva uholovnoho dela [Exclusion of inadmissible evidence from criminal proceedings] [dys. kand. yuryd. nauk]. Voronezh (in Russian).

Received: $05 / 01 / 2021$

1st revision: $30 / 01 / 2021$ Accepted: $10 / 02 / 2021$

S. Prylutskyi, Dr of Law, Associate Prof.

Taras Shevchenko National University of Kyiv, Kyiv, Ukraine

\title{
INSTITUTE OF EXCLUSION FROM EVIDENCE AT THE STAGE OF PRE-TRIAL INVESTIGATION: CURRENT PROBLEMS AND WAYS TO SOLVE THEM
}

The study focuses on both theoretical and applied aspects of evidentiary law. The subject of this study is the legal institution of admissibility of evidence in criminal proceedings, as well as the legal mechanism for declaring evidence inadmissible.

The author relies on the constitutional postulate (Part 3 of Article 62 of the Constitution of Ukraine) according to which the accusation cannot be based on evidence obtained illegally, as well as on assumptions. Based on this constitutional imperative, it is stated that the prosecution has no right to form charges and go to court if the accusation is based on illegal evidence or subjective assumptions, and emphasizes that the subject who forms the prosecution must operate on legal evidence. Thus, a legal contradiction is revealed between the provisions of the Constitution of Ukraine and Part 2 of Article 23 of the CPC of Ukraine regarding the legal nature of evidence in the pre-trial investigation.

Given that according to the domestic legal structure, factual data must be recognized as evidence at the stage of pre-trial investigation, there is a legal need to guarantee the right of a person to a fair trial, the introduction of a clear mechanism for verifying factual data for admissibility at the stage of pre-trial investigation. The author argues that such a mechanism should provide effective tools for self-control and neutralization of illegal sources of factual data by both the prosecuting authorities and the court, during the implementation of judicial control over pre-trial investigation in making key decisions to restrict guaranteed rights and freedoms.

Keywords: evidence, accusation, suspicion, admissibility of evidence, exclusion from evidence.

Bulletin of Taras Shevchenko National University of Kyiv. Legal Studies, 2021; 1 (116): 53-57

удк: 347.9

DOI: https:doi.org/10.17721/1728-2195/2021/1.116-11
ISSN $1728-2195$

(c) Taras Shevchenko National University of Kyiv, Publishing center "Kyiv University", 2020

О. Снідевич, канд. юрид. наук, доц. ORCID ID: 0000-0002-4255-3194

Київський національний університет імені Тараса Шевченка, Київ, Україна

\section{ЗАХОДИ ПРИМУСОВОГО ВИКОНАННЯ РІШЕНЬ ЯК ПРОЯВ ДИФЕРЕНЦІАЦІЇ ВИКОНАВЧОЇ ПРОЦЕСУАЛЬНОЇ ФОРМИ}

Присвячено аналізу поняття заходів примусового виконання рішень як прояву диференціації виконавчої процесуальної форми.

Обумовлено, що виконавча процесуальна форма під час виконання судових рішень і рішень інших органів не є єдиною для всіх виконавчих проваджень. Виконавець та інші учасники виконавчого провадження вчиняють у виконавчому провадженні різні за своєю зовнішньою формою та спрямування дії. Висловлено припущення, що у виконавчому процесі визначені законодавством про виконавче провадження заходи примусового виконання рішень є найбільш яскравим проявом диференціації виконавчої процесуальної форми.

У правовій науці поняття заходів примусового виконання рішень є дискусійним. Автор виокремлює в науці три підходи до розуміння цього поняття, які називає матеріально-правовим, матеріально-процесуальним і процесуальним.

Згідно з матеріально-правовим підходом заходи примусового виконання рішень $є$ санкцією за невиконання зобов'язання. Згідно з матеріально-процесуальним підходом заходи примусового виконання рішень є засобами реалізації санкцій. Зәідно з процесуальним підходом заходи примусового виконання рішень розглядаються як сукупність процесуальних дій на виконання рішення. Зроблено висновок, що кожен із зазначених підходів є обґрунтованим та усі вони в сукупності характеризують заходи примусового виконання рішень як багатоаспектне явище. Зосереджено увагу на більш детальному аналізі заходів примусового виконання рішень у процесуальному значенні.

Обґрунтовано, що заходи примусового виконання рішень є категорією, що диференціює виконавчу процесуальну форму. Ці заходи - це певна процесуальна модель виконання, певна сукупність процесуальних дій щодо виконання тих чи інших видів рішень. Кожен із виконавчих документів повинен виконуватися в межах визначеного заходу примусового виконання рішень.

За наслідками дослідження сформульовано авторське визначення заходів примусового виконання рішень.

Ключові слова: виконавче провадження, виконавча процесуальна форма, виконавчий процес, способи захисту прав, виконавець, виконавчий документ, заходи примусового виконання рішень.

ВСТУП. Поняття заходів примусового виконання рішень у правовій науці є дискусійним. Заходи примусового виконання рішень $є$ багатоаспектним поняттям, а тому досліджуються і в матеріально-правовому, і у процесуальному аспектах. У зв'язку з цим, висловлюються й різні підходи до розуміння цієї категорії виконавчого процесу.
Окремі дослідження щодо з'ясування сутності поняття "заходи примусового виконання рішень" здійснювали М. М. Агарков, Ю. В. Білоусов, І. В. Бондар, П. П. Заворотько, І. І. Зеленкова, Л. С. Малярчук, М. П. Омельченко, О. С. Снідевич, С. Я. Фурса, М. Й. Штефан, С. В. Щербак та інші. Однак, комплексно поняття 
заходів примусового виконання рішень як прояву диференціації виконавчої процесуальної фрорми досліджено не було.

Метою статті $€$ комплексне дослідження поняття заходів примусового виконання рішень, зокрема, виокремлення підходів щодо розуміння цього поняття в науці виконавчого процесу, їхній науковий аналіз, а також формулювання власного визначення поняття заходів примусового виконання рішень із позиції того, що вони $є$ проявом диференціації виконавчої процесуальної форми.

\section{ВИКЛАД ОСНОВНОГО МАТЕРІАЛУ.}

Загальні положення про диференціацію виконавчої процесуальної форми. Виконавча процесуальна форма під час виконання судових рішень і рішень інших органів не $є$ єдиною для всіх виконавчих проваджень. Незважаючи на те, що сама виконавча процесуальна форма вже $є$ наслідком поділу загальної процесуальної форми захисту прав на види, вона як і інші види процесуальної форми, що виокремлюються, підлягає своїй внутрішній диференціації. Наприклад, можна говорити про існування процесуальної фрорми виконання рішень немайнового характеру, які не можуть виконуватися без участі боржника [1]. I це не дивно. Задля виконання судового рішення виконавець та інші учасники виконавчого провадження не можуть вчиняти у виконавчому провадженні однакові за своєю зовнішньою формою дії. Ці дії $\epsilon$ різними за своїм спрямуванням, характером, наслідками, а їхнє вчинення в кожному конкретному випадку обумовлюється змістом резолютивної частини судового рішення чи іншого акта, що ії містить виконавчий документ, і визначеним законом процесуальним порядком виконання.

У процесуальній науці диференціація процесуальної форми пов'язується з якісно-кількісним поділом, деталізацією елементів процесуальної фрорми та її подальшим закріпленням у законодавстві. Проявом диференціації процесуальної форми визнаються, зокрема, види проваджень і стадії процесу. Водночас чи не найбільш яскравим проявом такої диференціації $є$ визначені законодавством види проваджень [2, с. 139-143].

Застосовуючи загальну теорію процесуального права до положень виконавчого процесу висловимо припущення, що в цьому процесі чи не найбільш яскравим проявом диференціації виконавчої процесуальної форми $€$ визначені законодавством про виконавче провадження заходи примусового виконання рішень.

Законодавство про виконавче провадження не надає визначення поняття заходів примусового виконання рішень, а містить тільки їхній перелік. Так, відповідно до ч. 1 ст. 10 Закону України "Про виконавче провадження" [3] (надалі - Закон) заходами примусового виконання рішень є: 1) звернення стягнення на кошти, цінні папери, інше майно (майнові права), корпоративні права, майнові права інтелектуальної власності, об'єкти інтелектуальної, творчої діяльності, інше майно (майнові права) боржника, зокрема якщо вони перебувають в інших осіб або належать боржникові від інших осіб, або боржник володіє ними спільно з іншими особами; 2) звернення стягнення на заробітну плату, пенсію, стипендію й інший дохід боржника; 3) вилучення в боржника і передача стягувачу предметів, зазначених у рішенні; 4) заборона боржнику розпоряджатися та/або користуватися майном, яке належить йому на праві власності, зокрема коштами, або встановлення боржнику обов'язку користуватися таким майном на умовах, визначених виконавцем; 5) інші заходи примусового характеру, передбачені цим Законом. Особливості кожного 3 них окреслюються в окремих частинах Закону.
Заходи примусового виконання рішень у правовій науці. У правовій науці поняття заходів примусового виконання рішень є дискусійним. Узагальнюючи висловлені в науці ще з радянських часів положення про заходи примусового виконання рішень можна прослідкувати три підходи до розуміння цього поняття, які на наш погляд, відповідно можна назвати матеріально-правовим, матеріально-процесуальним (змішаним) і процесуальним.

Згідно 3 матеріально-правовим підходом заходи примусового виконання рішень (вони ж називаються в літературі ще заходами безпосереднього примусу) $€$ санкцією за невиконання зобов'язання.

Так, ще в середині минулого століття М. М. Агарков висловив думку, що заходи безпосереднього примусу (звернення стягнення на майно боржника або позбавлення боржника свободи) є санкцією, що застосовується органами держави до порушників правових норм. Така санкція цивільно-правових норм, на його погляд, міститься не в самих цивільно-правових нормах, а в Цивільному процесуальному кодексі, норми якого передбачають порядок примусового стягнення [4, с. 415432]. Схожої позиції притримувався й С. С. Алєксєєв, зазначаючи, що специфічною ознакою цивільноправових санкцій є забезпечення (відновлення) раніше порушеного стану. Цивільно-правові санкції, що породжуються майновими відносинами та для захисту яких вони встановлюються, диктують необхідність у випадках настання відповідальності існування таких заходів примусового виконання, які б забезпечували реальність відновлення порушених цивільних прав [5, c. 167-168]. На наш погляд, таке розуміння заходів примусового виконання рішень ґрунтується на матеріально-правовій їхньої сутності, акцентує увагу на заходах як елементах відновлення порушеного матеріального права, а власне юридичний процес за такого підходу позбавлений самостійного значення та розглядається лише як матеріально-правова санкція за невиконання матеріально-правового зобов'язання.

Згідно з другим підходом, названим нами матеріально-процесуальним (змішаним), заходи примусового виконання рішень $€$ не санкціями, а засобами їхньої реалізації [6, с. 127 ]. Так, як зазначав О. С. Іоффее, не можна вважати заходом відповідальності реальне виконання, навіть якщо воно буде примусовим [7, с. 97]. Н. С. Малеін же вважав, що якщо вважати примусове виконання обов'язку (боргу) відповідальністю, слід прийти до висновку, що норми, які передбачають відповідні правові наслідки, цілком достатні, оскільки примусове виконання вже $€$ відповідальність. Сторона, яку спонукають виконати свої обов'язки, вже "відповідає". Якщо ж крім відповідальності у формі примусового виконання обов'язку стягувалися б ще збитки і штраф, то довелося б визнати, що господарський орган несе "подвійну" відповідальність [8, с. 13]. Ще більш чітко сутність цього підходу, на наш погляд, сформував П. П. Заворотько, який зазначав, що заходи примусового виконання $€$ формою (засобом) реалізації санкцій норм цивільного права тільки через виконання постанов судів та інших органів, які підлягають виконанню. I в цьому сенсі можна говорити, що заходи примусового виконання - остання "інстанція", яка охороняє від порушення норми цивільного права. Лише в цьому аспекті можна говорити, що заходи примусового виконання $€$ санкціями примусового здійснення невиконаних зобов'язань. Без таких санкцій багато правових зобов'язань були б нездійсненими [9, с. 311]. Отже, зазначений підхід розглядає заходи примусового виконання рішень одночасно як із матеріально-правової сторони, так і з 
процесуальної. Тут санкція за невиконання зобов'язання як матеріально-правова сторона заходів примусового виконання рішень обумовлює існування певної фрорми, імовірно - процесуальної.

Згідно з третім (процесуальним) підходом заходи примусового виконання рішень розглядаються виключно як категорія виконавчого провадження (виконавчого процесу).

Так, на думку І. І. Зеленкової під заходами примусового виконання рішень слід розуміти повноваження виконавця з примусового виконання рішення, передбачені законом, а також міри впливу на боржника, які мають стимулювати його до виконання рішення та не створювати перешкод у його виконанні [10, с. 31]. На думку ж Д. Х. Валєєва, під поняттям заходів примусового виконання рішень слід розуміти сукупність процесуальних дій певного характеру, визначених законодавством для виконання вимог виконавчого документа [11, с. 178]. Отже, зазначений підхід до розуміння заходів примусового виконання рішень обумовлений виключно процесуальними аспектами - процесуальними повноваженнями осіб, які здійснюють примусове виконання судових рішень і piшень інших органів, або ж процесуальними діями.

На наш погляд, кожен із висловлених у науці підходів до розуміння заходів примусового виконання рішень містить раціональне зерно та лише характеризує заходи примусового виконання рішень як багатоаспектне явище.

Зокрема, у процесі аналізу першого та другого підходів цілком обґрунтовано акцентується увага на тих матеріально-правових характеристиках, тих матеріально-правових передумовах, що обумовлюють існування заходів примусового виконання. Сутність процесуальної діяльності досить часто розглядається в теорії права через механізм реалізації матеріального права, захист якого здійснюється в судовій, адміністративній, нотаріальній тощо формах. Відтак, оскільки призначення процесу полягає в захисті матеріального права, то цілком очевидним, що й остання стадія цього процесу, якою $€$ виконавче провадження, $€$ нічим іншим як елементом захисту матеріального права. I завдяки цьому заходи примусового виконання рішень, які застосовуються на стадії виконання рішення, перебувають у безпосередньому зв'язку з матеріальним правом.

Однак, у процесі аналізу поняття "заходи примусового виконання рішень" не можна не звернути увагу, що це поняття досить широко використовується як процесуальне саме у процесуальному законодавстві, насамперед, у Законі. Відтак, цілком обґрунтованим виглядає розгляд цього поняття безпосередньо у процесуальному значенні. А таке його значення, як показано буде нижче, є зовсім іншим від того, як воно тлумачиться 3 матеріально-правового погляду.

Ураховуючи наведене, залежно від мети дослідження прийнятним $\epsilon$ використання того чи іншого підходу до розуміння заходів примусового виконання рішень, а аналіз його у різних значеннях сприяє більш глибшому пізнанню цього явища. Зосередимось на більш детальному аналізі заходів примусового виконання рішень саме у процесуальному значенні. Принагідно відзначимо, що процесуальний підхід до розуміння заходів примусового виконання рішень, на відміну від перших двох підходів, використовують переважно вчені-процесуалісти, що досліджують особливості виконавчого провадження (виконавчого процесу).

Під час визначення поняття заходів примусового виконання рішень вважаємо недосконалим те 3 них, яке було запропоноване І.І. Зеленковою. Пояснюється це тим, що воно не враховує розуміння заходів примусового виконання рішень як категорії, що диференціює ви- конавчий процес. Як уже зазначалося вище, під заходами примусового виконання рішень І.І. Зеленкова розуміє повноваження виконавця з примусового виконання рішення, передбачені законом, а також міри впливу на боржника, які мають стимулювати його до виконання рішення та не створювати перешкод у його виконанні $[10$, с. 31]. Обумовимо, що положення ст. 10 Закону, яка містить перелік заходів примусового виконання рішень, взагалі ніяк не співвідносить повноваження виконавця та заходи примусового виконання. Крім того, важливим $€$ те, що це положення Закону не визначає єдиного заходу примусового виконання рішень, а проводить їхню диференціацію. Через це ймовірне визначення відповідного поняття повинне це враховувати. Також навряд чи доцільним $є$ розгляд заходів примусового виконання у запропонованому значенні і в теорії виконавчого процесу. Повноваження виконавця $€$ самостійним інститутом виконавчого процесу та досліджуються через сукупність його прав та обов'язків. Аналогічно навряд чи варто розглядати під заходами примусового виконання рішень і міри впливу на боржника, які мають стимулювати його до виконання рішення та не створювати перешкод у його виконанні. Зазначені міри впливу $є$ більше, так званими заходами непрямого впливу, а не заходами примусового виконання рішень.

Більш прийнятним є визначення, яке було запропоноване Д. Х. Валєєвим, згідно з яким заходами примусового виконання рішень $є$ сукупністю процесуальних дій певного характеру, визначених законодавством для виконання вимог виконавчого документа [11, с. 178]. По-перше, таке визначення окреслює можливість диференціації заходів примусового виконання рішень (оскільки містить вказівку на певний характер процесуальних дій), а по-друге - не містить у собі дублювання інших категорій виконавчого процесу.

Визначення поняття "заходи примусового виконання рішень" із позиції диференціації виконавчої процесуальної форми. У процесі визначення поняття заходів примусового виконання рішень необхідно враховувати, що процесуальні дії, спрямовані на примусове виконання виконавчих документів, не можуть бути однаковими за своїм змістом щодо всіх виконавчих документів. Кожне з рішень, яке підлягає виконанню, передбачає вчинення виконавцем та іншими суб'єктами виконавчого процесу своєї сукупності процесуальних дій у межах відповідних процедур виконання (моделей, видів проваджень). Не може, наприклад, виконавець під час виконання рішень про стягнення коштів із боржника чи про його виселення вчиняти однакові процесуальні дії, бо сутність зобов'язань у кожному з цих випадків $€$ різною. I тут досить важливим як для практики, так і для теорії, $є$ розробка та врегулювання у нормативних актах чітких моделей (проваджень) щодо виконання рішень окремих категорій.

Як вбачається $з$ аналізу положень Закону, у ньому використання терміну "заходи примусового виконання рішень" позбавлене єдиного значення. Справді, у окремих положеннях Закону поняття заходів примусового виконання рішень вживається й у значенні, досить близькому до висловленого І.І. Зеленковою розуміння. Однак, більш ціннішим для практики та науки є те їхнє розуміння, що міститься у ст. 10 Закону. Саме з неї вбачається, що заходи примусового виконання рішень $€$ категорією, що диференціює виконавчу процесуальну форму. У ній ці заходи $є$ певною процесуальною моделлю виконання, певною сукупністю процесуальних дій щодо виконання тих чи інших видів рішень. Фактично захід примусового виконання - це як вид провадження у судочинстві, коли кожна із судових справ роз- 
глядається у своєму наперед визначеному провадженні. Аналогічно і у виконавчому процесі - кожний з виконавчих документів повинен виконуватися в межах свого виду провадження - заходу примусового виконання рішень (але безумовно з урахуванням своєї специфіки, яка полягає в можливості виконання рішення та в межах декількох заходів примусового виконання рішень).

Заходи примусового виконання рішень у зазначеному значенні мають безпосередній зв'язок зі способами захисту матеріального права. Фактично можна стверджувати, що вони безпосередньо обумовлюються цими способами. Так, аналізуючи поняття способів захисту порушених прав, Ю. Д. Притика обґрунтовано зазначає, що способи захисту права як дії є завершальними актами захисту у вигляді матеріально-правових дій або юрисдикційних дій, які спрямовані на усунення перешкод на шляху здійснення суб'єктами своїх прав (інтересів) або на припинення правопорушення, відновлення положення, що існувало до правопорушення [12, с. 22]. Спосіб захисту права $€$ умовною правовою моделлю захисту як примусової реалізації суб'єктивного права, яка враховує: а) потенційну можливість (передумови) вчинення учасниками матеріальних правовідносин i/або компетентними державними чи недержавними органами дій, спрямованих на відновлення порушених суб'єктивних прав учасника правовідносин; б) зазначені дії цих суб'єктів і в) правові наслідки у вигляді відновленого порушеного права [13, с. 276-277]. Для нас очевидним $€$ те, що у випадку примусового виконання рішення юрисдикційного органу такі завершальні дії вчиняються і у виконавчому провадженні, а їхній зміст обумовлюється тим способом захисту, який був визначений юрисдикційним органом у своєму рішенні. Цей зміст проявляється в окремих заходах примусового виконання рішень, які і $є$ завершальним етапом реалізації захисту права як процесу, складовою загальної моделі захисту, у межах якої й вчиняються органами примусового виконання рішень та іншими суб'єктами процесуальні дії щодо виконання рішення юрисдикційного органу.

3 урахуванням наведеного, вважаємо, що заходами примусового виконання рішень $є$ врегульовані нормами виконавчого процесуального права особливі порядки (процедури) примусового виконання рішень окремих категорій у межах виконавчої процесуальної форми, які визначається системою взаємопов'язаних виконавчих процесуальних прав та обов'язків і процесуальних дій учасників виконавчого провадження.

Запропоноване розуміння заходів примусового виконання рішень, на наш погляд, має теоретичне та практичне значення. Не важко помітити, що перелік заходів примусового виконання рішень у ст. 10 Закону $є$ досить вузьким, а сам Закон не передбачає моделей виконання окремих рішень або врегульовує їх досить поверхнево. Відтак, завданням науки виконавчого процесу й законодавця натепер $€$ вибудовування окремих заходів примусового виконання рішень як процесуальних процедур, моделей виконання рішень окремих категорій, у межах яких повинні вчинятися процесуальні дії кожним з учасників виконавчого процесу. Причому критерієм правильності побудови таких процедур повинна бути ефективність процесуальних дій, які вчиняються на практиці, реальне виконання рішення.

ВИСНОВкИ. У виконавчому процесі визначені законодавством про виконавче провадження заходи примусового виконання рішень $€$ найбільш яскравим проявом диференціації виконавчої процесуальної форми.

Заходами примусового виконання рішень $€$ врегульовані нормами виконавчого процесуального права особливі порядки (процедури) примусового виконання рішень окремих категорій у межах виконавчої процесуальної форми, які визначаються системою взаємопов'язаних виконавчих процесуальних прав та обов'язків і процесуальних дій учасників виконавчого провадження.

Список використаної літератури

1. Снідевич О. С. Процесуальна форма виконання рішень немайнового характеру, які не можуть бути виконані без участі боржника / О. С. Снідевич // Підприємництво, господарство і право. - 2019. - № 6. - C. $52-56$.

2. Зуб А. А. Дифференциация гражданской процессуальной формы сквозь призму синергетики и теоретического моделирования / А. А. Зуб. // Jurnalul juridic naţional: teorie şi practică. - 2015. - № 6. - C. 139-143.

3. Про виконавче провадження: Закон України від 02.06.2016. № 1404-VIII [Електронний ресурс]. - Режим доступу : https://zakon.rada.gov.ua/ laws/show/1404-19\#Text (дата звернення: 01.02.2021).

4. Теория государства и права: макет учебника / науч. ред. М.А. Аржанов. - М., Б.и., 1948. 500 с.

5. Алексеев С. С. Гражданское право в период развернутого строительства коммунизма / С. С. Алексеев. - М. : Госюриздат, 1962.

6. Завадская Л. Н. Реализация судебных решений. Теоретические аспекты / Л. Н. Завадская. - М. : Наука, 1982.

7. Иоффе О. С. Обязательственное право / О. С. Иоффре. - М. : Юрид. лит-ра, 1975.

8. Малеин Н. С. Имущественная ответственность в хозяйственных отношениях / Н. С. Малеин. - М. : Наука, 1968.

9. Заворотько П. П. Процессуальные гарантии исполнения судебного решения / П. П. Заворотько. - М. : Юрид. лит-ра. 1974.

10. Зеленкова І. І. Процедура звернення стягнення на майно боржника у виконавчому процесі : дис ... канд. юрид. наук: 12.00.03; НАН України; Київський ун-т права / І. І. Зеленкова. - Івано-Франківськ, 2017.

11. Валеев Д. Х. Система процессуальных гарантий прав граждан и организаций в исполнительном производстве / Д. Х. Валеев. - М. Статут, 2009.

12. Притика Ю. Д. Проблеми захисту цивільних прав та інтересів у третейському суді / Ю. Д. Притика. - К. : Вид. Дім "Ін Юре", 2006.

13. Мягкоход Ю. В. Спосіб захисту суб'єктивних земельних прав: формулювання поняття / Ю. В. Мягкоход // Часопис Київ. ун-ту права. 2013. - № 3. - C. 274-278.

\section{References}

1. Snidevych, O. (2019) Protsesualna forma vykonannia rishen nemainovoho kharakteru, yaki ne mozhut buty vykonani bez uchasti borzhnyka [Procedural form of execution of a non-material nature decisions, which cannot be executed without the participation of the debtor]. Pidpryiemnytstvo, hospodarstvo i pravo [Entrepreneurship, economy and law] (52) (in Ukrainian).

2. Zub, A. (2015) Differenciacija grazhdanskoj processual'noj formy skvoz' prizmu sinergetiki i teoreticheskogo modelirovanija [Differentiation of civil procedural form through the prism of synergetics and theoretical modeling]. Jurnalul juridic naţional: teorie şi practică, (139), 139-143 (in Ukrainian).

3. Pro vykonavche provadzhennia [On executive proceedings], Zakon Ukrainy [Law of Ukraine] (2016) № 1404-VIII. https://zakon.rada.gov.ua/ laws/show/1404-19\#Text (accessed: 01.02.2021) (in Ukrainian)

4. Teorija gosudarstva i prava: maket uchebnika [Theory of State and Law] (1948) (in Russian).

5. Alekseev, S. (1962) Grazhdanskoe pravo v period razvernutogo stroitel'stva kommunizma [Civil law during the extended construction of communism]. Gosjurizdat (in Russian)

6. Zavadskaja, L. (1982) Realizacija sudebnyh reshenij. Teoreticheskie aspekty [Implementation of court decisions. Theoretical aspects]. Nauka (in Russian)

7. loffe, O.S. (1975) Objazatel'stvennoe pravo [Obligation law]. Juridicheskaja literatura (in Russian).

8. Malein, N. (1968) Imushhestvennaja otvetstvennost' v hozjajstvennyh otnoshenijah [Property liability in economic relations]. Nauka (in Russian).

9. Zavorot'ko, P. (1974) Processual'nye garantii ispolnenija sudebnogo reshenija [Procedural guarantees for the execution of a judgment]. Juridicheskaja literature (in Russian).

10. Zelenkova, I. (2017) 'Protsedura zvernennia stiahnennia na maino borzhnyka u vykonavchomu protsesi' ['The procedure for recovery of the debtor's property in the executive process'] [DPhil thesis]. Kyivskyi universytet prava (in Ukrainian).

11. Valeev, D. (2009) Sistema processual'nyh garantij prav grazhdan i organizacij $v$ ispolnitel'nom proizvodstve [The system of procedural guarantees of the rights of citizens and organizations in executive proceedings]. Statut (in Russian).

12. Prytyka, Yu. (2006) Problemy zakhystu tsyvilnykh prav ta interesiv u treteiskomu sudi [Problems of protection of civil rights and interests in arbitration]. Vydavnychyi Dim "In Yure" (in Ukrainian)

13. Miahkokhod, Yu. (2013) Sposib zakhystu sub'iektyvnykh zemelnykh prav: formuliuvannia poniattia [Method of protection of subjective land rights: formulation of the concept]. Chasopys Kyivskoho universytetu prava [Journal of Kyiv University of Law], (3), 274 (in Ukrainian).

Received: $12 / 01 / 2021$ 1st revision: 08/02/2021 Accepted: 20/02/2021 
O. Snidevych, PhD (Law), Associate prof.

Taras Shevchenko National University of Kyiv, Kyiv, Ukraine

\section{MEASURES FOR THE ENFORCEMENT OF JUDGMENTS AS MANIFESTATION OF DIFFERENTIATION OF EXECUTIVE PROCEDURAL FORM}

The article deals with the analysis of the concept of the enforcement of judgments as the manifestation of differentiation of the executive procedural form.

It is stipulated that the executive procedural form in the execution of court decisions and decisions of other authorities is not the same for all enforcement proceedings. The executor and other participants of the enforcement proceeding perform different functions in the enforcement proceeding. It is suggested that in the enforcement process the measures for the enforcement of judgment, stipulated by the legislation on enforcement proceedings are the most striking manifestation of the executive procedural form.

In legal studies the concept of the measures for the enforcement of judgments remains controversial. The author distinguishes three approaches to understanding of this concept, he calls them substantive-legal, substantive-procedural and procedural.

According to the substantive-legal approach, measures for enforcement of judgments are a sanction for non-compliance. Under the substantive-procedural approach, measures for the enforcement of judgments are the means of implementation of sanctions. Based on the procedural approach, measures for enforcement of judgments are considered as a set of procedural actions to enforce the decision. It is concluded that each of these approaches is justified and all of them together characterize the measures for enforcement of judgments as a multifaceted phenomenon. The article focuses on more detailed analysis on the enforcement of judgments in procedural sense.

It is proved that the measures for the enforcement of judgments are a category that differentiates the executive procedural form. These measures are a certain procedural pattern of enforcement, a distinct set of procedural actions, connected with the enforcement of different decisions. Every writ of execution should be performed within the frames of a certain measure for the enforcement of judgments.

As the result of the research the author formulates his own definitions of the measures for the enforcement of judgments.

Keywords: enforcement proceeding, executive procedural form, enforcement procedure, means of rights protection, executor, writ of execution, measures for enforcement of judgments.

Bulletin of Taras Shevchenko National University of Kyiv. Legal Studies, 2021; 1 (116): 57-61

УдК: $341.01+342$

DOI: https:doi.org/10.17721/1728-2195/2021/1.116-12
ISSN 1728-2195

(C) Taras Shevchenko National University of Kyiv, Publishing center "Kyiv University", 2020

О. Стрєльцова, д-р юрид. наук, доц. ORCID ID: 0000-0002-0907-2049

Київський національний університет імені Тараса Шевченка, Київ, Україна

\section{КОНСТИТУЦІОНАЛІЗАЦІЯ СПІВРОБІТНИЦТВА УКРАЇНИ 3 ЄС НА ПІДСТАВІ УГОДИ ПРО АСОЦІАЦІЮ: ПЕРСПЕКТИВИ РОЗВИТКУ}

Досліджується процес конституціоналізації асоціативних відносин між Україною та Європейським Союзом. Автор виокремлює й розкриває два основні аспекти цього процесу: змістовний та імплементаційний. Визначається, що змістовна конституціоналізація по своїй суті є конституційною модернізацією, у ході якої відбувається змістовне оновлення положень Конституції з метою формування конституційних засад для подальшої демократизації суспільно-політичного життя в Україні, наближення національної політико-правової системи до європейських цінностей $і$ принципів, удосконалення внутрішньодержавної законодавчої бази. Імплементаційний аспект конституціоналізації полягає в цілеспрямованому формуванні конституційних передумов для імплементації положень Угоди про асоціацію до національної системи права. Автор вважає, що здійснення як змістовної, так і імплементаційної конституціоналізації асоціації України з ЄС можна реалізувати лише шляхом включення цього процесу безпосередньо в контекст конституційної реформи в Україні.

Звертається увага на певні проблеми реформування Конституції України у зв'язку із забезпеченням європейської інтеграції та висловлюються критичні застереження, пов'язані з доповненням Конституції положеннями щодо стратегічного курсу України на довготривалу перспективу.

Ключові слова: Конституція України, конституційна реформа, конституціоналізація, Європейський Союз, Угода про асоціацію між Украӥною та $Є C$.

ВСтУП. Підписавши Угоду про асоціацію з Європейським Союзом (далі - ЄС), Україна взяла на себе зобов'язання вдосконалити внутрішньодержавну правову базу, привести її у відповідність із європейськими стандартами. У цьому контексті чи не найбільшої уваги потребують положення Основного закону держави - Конституції. І це зрозуміло, оскільки саме в Конституції концентровано відображені підходи держави до міжнародного співробітництва, саме вона $є$ тим елементом правової системи, що здатен ефективно регулювати діяльність як у внутрішньодержавній, так і в зовнішньополітичній сферах, сприяти належному захисту національних інтересів.

3 іншого боку, проблеми зміни норм Основного закону, скасування чинних або включення нових положень, що регламентують питання, пов'язані з міжнародними відносинами, актуалізуються у зв'язку із загальними процесами конституційного реформування, зок- рема із внесенням в лютому 2019 р. до Конституції України змін, які визначили стратегічний курс держави на набуття повноправного членства України в ЄС.

Виходячи із зазначеного, метою статті $\boldsymbol{\epsilon}$ дослідження змістовного та імплементаційного аспектів конституціоналізації асоціації України з ЄС як основи цього процесу й аналіз проблемних аспектів і подальших перспектив реалізації визначеного в Конституції України стратегічного курсу нашої держави на набуття повноправного членства в ЄС.

Питання конституційних змін не є новим для України і вже неодноразово ставало як предметом політичних дискусій, так і об'єктом наукових досліджень. До характеристики тих чи інших аспектів цього процесу зверталися у своїх дослідженнях такі вітчизняні науковці, як Ю. Барабаш, Ю. Волошин, В. Кампо, А. Крусян, М. Орзіх, Н. Пархоменко, С. Погребняк, Т. Подорожна, О. Скрипнюк, В. Шамрай, Я. Чернопищук та ін. Разом із тим, роз- 